Article

\title{
Synthesis, Crystal Structure Analysis and Decomposition of $\mathrm{RbAlH}_{4}$
}

\author{
Claudia Weidenthaler ${ }^{1, *(1)}$, Michael Felderhoff ${ }^{1}$, Thomas Bernert ${ }^{1}$, Magnus H. Sørby ${ }^{2}$, \\ Bjørn C. Hauback ${ }^{2}$ and Daniel Krech ${ }^{1}$ \\ 1 Max-Planck-Institut für Kohlenforschung, D-45470 Mülheim an der Ruhr, Germany; \\ felderhoff@mpi-muelheim.mpg.de (M.F.); thomas.bernert1@gmx.de (T.B.); d.krech@yahoo.de (D.K.) \\ 2 Institute for Energy Technology (IFE), P.O. Box 40, NO-2027 Kjeller, Norway; Magnus.Sorby@ife.no (M.H.S.); \\ Bjorn.Hauback@ife.no (B.C.H.) \\ * Correspondence: weidenthaler@mpi-muelheim.mpg.de; Tel.: +49-208-306-2181
}

Received: 31 January 2018; Accepted: 21 February 2018; Published: 22 February 2018

\begin{abstract}
RbAlH}_{4}$, a member of the complex metal aluminum hydride family, can be synthesized phase pure by different synthesis routes. Synthesis from the metals by a mechanochemical reaction requires the presence of a catalyst, but also emphasizes the reversibility of hydrogenation. The structure refinement of neutron diffraction data confirms that $\mathrm{RbAlD}_{4}$ is isostructural to $\mathrm{KAlD}_{4}$. The decomposition proceeds via two distinct processes at temperatures above $275^{\circ} \mathrm{C}$. However, the structures formed during decomposition seem to be different from the compounds formed during hydrogen release of early alkali metal aluminum hydrides.
\end{abstract}

Keywords: complex metal aluminum hydrides; hydrogen storage; crystal structure

\section{Introduction}

$\mathrm{RbAlH}_{4}$ belongs to the family of complex metal aluminum hydrides, which have been studied intensively as potential candidates for reversible hydrogen storage in solid-state materials [1-3]. For both groups, alkali and alkaline earth aluminum hydride crystalline structures are obtained after synthesis, which are built from isolated $\left[\mathrm{AlH}_{4}\right]^{-}$anions coordinating the metal cations, $\mathrm{Me}^{+/ 2+}$. So far, the known tetrahedral structures, $\mathrm{MeAlH}_{4}$ or $\mathrm{Me}\left(\mathrm{AlH}_{4}\right)_{2}$ with $\mathrm{Me}$ representing the alkali and alkaline earth metal cations, release hydrogen in defined dehydrogenation steps. For the light alkali metal aluminum hydrides, the subsequent decomposition steps are described in Scheme 1. First, a part of the hydrogen is released, and intermediate hexahydride structures, $\mathrm{Me}_{3} \mathrm{AlH}_{6}$, are formed together with metallic aluminum. For the $\mathrm{Li}, \mathrm{K}$, and $\mathrm{Na}$ compounds, the intermediate structures are built of isolated $\left[\mathrm{AlH}_{6}\right]^{3-}$ octahedra (Figure 1a), which decompose in a second step, forming the simple hydrides $\mathrm{MeH}, \mathrm{Al}$, and $\mathrm{H}_{2}$. Further heating leads to the complete decomposition of the hydrides to metals and hydrogen.

$$
\begin{aligned}
& 3 \mathrm{MeAlH}_{4} \longrightarrow \mathrm{Me}_{3} \mathrm{AlH}_{6}+2 \mathrm{Al}+3 \mathrm{H}_{2} \\
& \mathrm{Me}_{3} \mathrm{AlH}_{6} \longrightarrow 3 \mathrm{MeH}+\mathrm{Al}+1.5 \mathrm{H}_{2} \\
& \mathrm{Me}=\mathrm{Li}, \mathrm{Na}, \mathrm{K}
\end{aligned}
$$

Scheme 1. Decomposition steps of alkali metal aluminum hydrides.

For the alkaline earth aluminum hydrides the decomposition and the intermediate structures are different. While for $\mathrm{Mg}\left(\mathrm{AlH}_{4}\right)_{2}$ so far only the direct decomposition to $\mathrm{MgH}_{2}$ has been observed [4,5], 
intermediate structures have been reported for the Ca, Sr, and Ba compounds (Scheme 2) [6-9]. The crystal structures of the alkaline earth aluminum intermediates consist of corner-sharing octahedra forming chains in different conformations. The octahedra can either form helical chains along the crystallographic $c$-axis as determined for $\mathrm{CaAlH}_{5}[6]$ or a zig-zag like arrangement as observed for $\mathrm{SrAlH}_{5}$ and $\mathrm{BaAlH}_{5}$ (Figure 1b) [9].

$$
\begin{aligned}
& \operatorname{Me}\left(\mathrm{AlH}_{4}\right)_{2} \longrightarrow \mathrm{MeAlH}_{5}+\mathrm{Al}+1.5 \mathrm{H}_{2} \\
& \mathrm{MeAlH}_{5} \longrightarrow \mathrm{MeH}_{2}+\mathrm{Al}+1.5 \mathrm{H}_{2} \\
& \mathrm{Me}=\mathrm{Mg}, \mathrm{Ca}, \mathrm{Sr}, \mathrm{Ba}
\end{aligned}
$$

Scheme 2. Decomposition steps of alkaline earth metal aluminum hydrides.

The second hydrogen release step leads to the formation of simple hydrides, such as $\mathrm{SrH}_{2}$ or $\mathrm{CaH}_{2}$. The final decomposition step leads to the formation of intermetallic compounds of type $\mathrm{Me}_{\mathrm{x}} \mathrm{Al}_{\mathrm{y}}$. The crystal structure principles of the intermediates are shown in Figure 1, with $\mathrm{Na}_{3} \mathrm{AlD}_{6}[10]$ as representative for the alkali metal aluminum hydride and $\mathrm{CaAlD}_{5}$ [6] for the alkaline earth aluminum hydride.

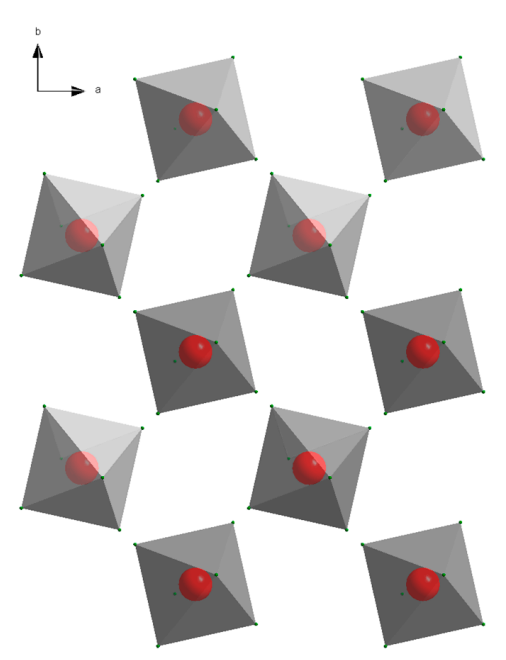

(a)

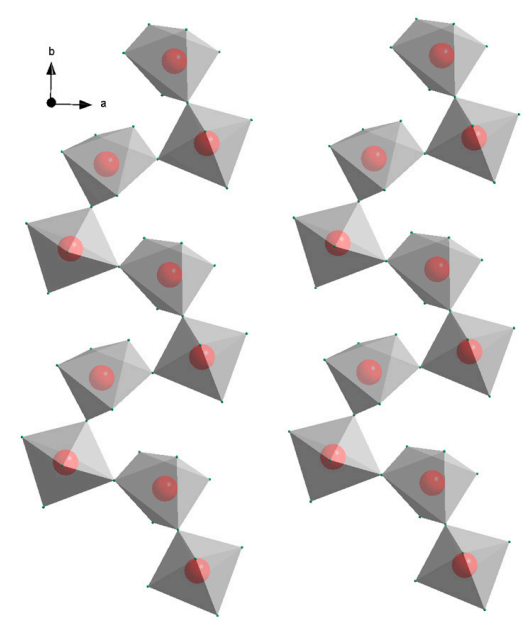

(b)

Figure 1. (a) Section of the crystal structure of $\mathrm{Na}_{3} \mathrm{AlD}_{6}$ considering only the arrangement of the isolated $\left[\mathrm{AlH}_{6}\right]^{3-}$ octahedra. (b) Section of the $\mathrm{CaAlD}_{5}$ crystal structure, showing two helical chains of corner-sharing $\left[\mathrm{AlH}_{6}\right]^{3-}$ octahedra.

Based on these results, the crystal structures and the decomposition pathways of aluminum hydrides containing heavier and larger $\mathrm{Rb}^{+}$and $\mathrm{Cs}^{+}$cations were expected to be similar to the known compounds. However, recently published results on $\mathrm{CsAlH}_{4}$ showed that even though the crystal structure is related to the $\mathrm{NaAlH}_{4}$ structure, the compound with the large cation has some different structural properties and decomposition behavior. Interestingly, $\mathrm{CsAlH}_{4}$ crystallizes into two polymorphic structures, which undergo reversible phase transformations [11,12]. Contrary to the lightweight alkali aluminum hydrides, the decomposition does not follow the steps shown in Scheme 1.

The synthesis of $\mathrm{RbAlH}_{4}$ and the first spectroscopy data were described almost 50 years ago [13]. The hydride was synthesized by an exchange reaction between $\mathrm{LiAlH}_{4}$ and $\mathrm{Rb}$ metal. From the infrared data it was concluded that the structure of $\mathrm{RbAlH}_{4}$ consists of $\left[\mathrm{AlH}_{4}\right]^{-}$tetrahedra. Gavrilenko et al. report the synthesis of $\mathrm{RbAlH}_{4}$ by a reaction between alkylated tetrahydroaluminates or 
tetraalkylonium cations with $\mathrm{LiAlH}_{4}$ in ether [14]. A wet-chemical synthesis route for the preparation of $\mathrm{RbAlH}_{4}$ was published by Bastide et al. [15]. The authors measured powder X-ray diffraction (PXD) data and analyzed the data by a least square refinement of the lattice parameters resulting in an orthorhombic unit cell $(a=9.253, b=5.950, c=7.599 \AA)$. The structure was related to barite-type but no atomic positions were determined from the diffraction data. The complete crystal structure of $\mathrm{RbAlH}_{4}$, including hydrogen positions, was first predicted by first-principle density-functional-calculations (DFT) [16]. Calculations were based on the orthorhombic space group, Pnma with $\mathrm{Rb}$ and $\mathrm{Al}$ both on Wyckoff position 4c.

In this work, different mechanochemical synthesis procedures for the preparation of $\mathrm{RbAlH}_{4}$, crystal structure analysis based on powder X-ray and neutron diffraction data, and first results on the decomposition of $\mathrm{RbAlH}_{4}$ will be addressed.

\section{Materials and Methods}

\subsection{Synthesis Procedure and Reagents}

The synthesis of $\mathrm{RbAlH}_{4}$ can be achieved by ball-milling using two different procedures. The first route is the synthesis of $\mathrm{RbAlH}_{4}$ by ball-milling of $\mathrm{RbCl}$ or $\mathrm{RbF}$ and $\mathrm{NaAlH}_{4}$ or $\mathrm{LiAlH}_{4}$. For the deuterated forms, $\mathrm{LiAlD}_{4}$ is used instead of $\mathrm{LiAH}_{4}$. This step is followed by a heating treatment in an autoclave and a subsequent purification via dissolution in diglyme and precipitation in toluene (Scheme 3) [17].

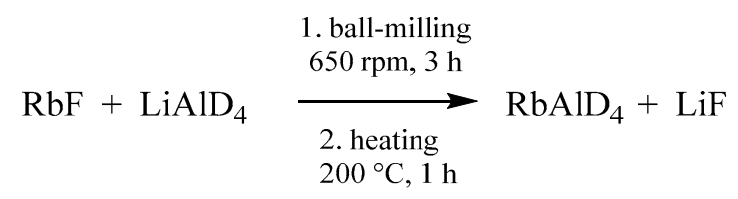

Scheme 3. Synthesis of $\mathrm{RbAlD}_{4}$ starting form $\mathrm{RbF}$ and $\mathrm{LiAlD}_{4}$.

Commercial $\mathrm{LiAlD}_{4}(>90 \%, 98 \%$ D, ABCR) and RbF (99\%, Sigma Aldrich, St. Louis, MO, USA) were used without further purification. Used solvents were carefully dried, followed by distillation. Ball-milling experiments were carried out in a Pulverisette P7 (Fritsch, Idar-Oberstein, Germany) planetary ball-mill, using hardened steel balls and vessels.

$\mathrm{RbAlD}_{4}$ was prepared by ball-milling $\mathrm{RbF}(1.0 \mathrm{~g}, 9.6 \mathrm{mmol})$ and $\mathrm{LiAlD}_{4}(0.402 \mathrm{~g}, 9.6 \mathrm{mmol}$, $)$ with 4 balls ( $5.0 \mathrm{~g}$ each, $10 \mathrm{~mm}$ diameter) at a rotational speed of $650 \mathrm{rpm}$. The milling time was set to three hours with a break of $10 \mathrm{~min}$ after each hour. Afterwards, the sample was heated in an autoclave to $200{ }^{\circ} \mathrm{C}$ for $1 \mathrm{~h}$ to complete the reaction. For purification, the sample was transferred into a Schlenk flask and suspended in 1-methoxy-2-(2-methoxyethoxy) ethane (diglyme) and stirred at room temperature for $1 \mathrm{~h}$. The suspension was filtered through a P4 frit into toluene. The precipitated $\mathrm{RbAlD}_{4}$ was filtered off and carefully dried in vacuum.

Another option to produce $\mathrm{RbAlH}_{4}$ is the direct synthesis starting from the metals, $\mathrm{Rb}$ and $\mathrm{Al}$ (Scheme 4) [18]. For the direct synthesis of $\mathrm{RbAlH}_{4}$ commercial Rb-metal (99.9\%, ABCR), Al-metal (99.5\%, Sigma Aldrich) and $\mathrm{TiCl}_{3}$ (99.995 Sigma Aldrich) were used. Ball-milling experiments were carried out in a Pulverisette P6 (Fritsch), using a high pressure milling vial constructed for hydrogen pressure $\mathrm{p}_{\max }=30 \mathrm{MPa}$.

$\mathrm{Rb}(1.158 \mathrm{~g}, 13.55 \mathrm{mmol}), \mathrm{Al}(0.366 \mathrm{~g}, 13.55 \mathrm{mmol})$ and $\mathrm{TiCl}_{3}(0.105 \mathrm{~g}, 0.68 \mathrm{mmol})$ were transferred into the high-pressure milling vial (10 balls hardened steel, $4 \mathrm{~g}$ each, diameter $9.8 \mathrm{~mm}$ ) and pressurized to $20 \mathrm{MPa} \mathrm{H}_{2}$. The first hydrogenation (synthesis of $\mathrm{RbH}$ ) was done at a rotational speed of $250 \mathrm{rpm}$ for $1 \mathrm{~h}$ (10 min break) and the second reaction step (synthesis of $\mathrm{RbAlH}_{4}$ ) was done at a rotational speed of $450 \mathrm{rpm}$ for $4 \mathrm{~h}$. Purification process was similar to the synthesis of $\mathrm{RbAlD}_{4}$ as described above

Rubidium is a very soft and ductile material. Starting from the pure metals $\mathrm{Rb}$ and $\mathrm{Al}$, direct synthesis must be performed in several steps. The hydrogenation of $\mathrm{Rb}$ to $\mathrm{RbH}$ under mechanochemical 
conditions was performed at low revolutions per minute $(250 \mathrm{rpm})$. Otherwise, the metal is smeared over the wall of the milling vial and no complete hydrogenation can be observed [19]. In the next step, the mechanochemically induced hydrogenation of the $\mathrm{RbH}-\mathrm{Al}$ mixture can be done with $450 \mathrm{rpm}$ to produce $\mathrm{RbAlH}_{4}$ by ball-milling under $20 \mathrm{MPa} \mathrm{H}_{2}$ pressure for $5 \mathrm{~h}$ according to Scheme 4 . However, this synthesis requires the addition of $5 \mathrm{~mol}^{\%} \mathrm{TiCl}_{3}$ for a successful synthesis.

$$
\begin{aligned}
& \text { ball-milling } \\
& \text { (1) } 250 \mathrm{rpm}, 1 \mathrm{~h} \\
& \text { (2) } 450 \mathrm{rpm}, 4 \mathrm{~h}
\end{aligned}
$$

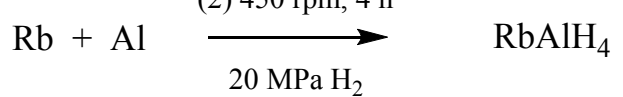

$$
\begin{aligned}
& 5 \mathrm{~mol}^{\%} \mathrm{TiCl}_{3}
\end{aligned}
$$

Scheme 4. Synthesis of $\mathrm{RbAlH}_{4}$ starting from the pure metals.

All operations were performed under an inert argon atmosphere by using a glove box or common Schlenk techniques.

\subsection{Powder X-ray Diffraction}

Prior to analysis, all samples were filled into $0.5 \mathrm{~mm} \varnothing$ glass capillaries and sealed to prevent any contact with air. Powder X-ray diffraction (PXD) experiments were carried out in Debye-Scherrer transmission geometry on a STOE STADI P diffractometer using Cu K $\alpha_{1}(\lambda=1.54056 \AA)$ radiation. Data were collected with a position sensitive detector in the 6-80 $2 \theta$ range with an acquisition time of $60 \mathrm{~s}$ per measuring point. Rietveld refinements were performed with TOPAS Version 5 (Bruker AXS, Karlsruhe, Germany).

For the decomposition studies, samples were filled in a glove box into $0.5 \mathrm{~mm} \varnothing$ quartz glass capillaries. The capillaries were transported under protective atmosphere to a capillary furnace. Since hydrogen evolution during decomposition reaction can lead to the destruction of the quartz glass capillaries the capillaries were not sealed but kept under a continuous Ar flow. In a first series of experiments (not shown here), samples were heated from room temperature to $350{ }^{\circ} \mathrm{C}$ in temperature steps of 50 and $25^{\circ} \mathrm{C}$. Based on the screening experiments, defined temperatures were selected that showed significant changes in the diffraction patterns. A sample was heated to $300{ }^{\circ} \mathrm{C}$ with a heating rate of $1{ }^{\circ} \mathrm{C} \mathrm{min}^{-1}$. After cooling to room temperature, data were collected on a STOE STADI P diffractometer (STOE, Darmstadt, Germany) using $\mathrm{Cu} \mathrm{K} \alpha_{1}$ radiation. Afterwards the same sample was heated to 325 and $350^{\circ} \mathrm{C}$. After reaching the temperature, the samples were cooled down to room temperature and X-ray powder patterns were collected.

\subsection{Powder Neutron Diffraction}

The powder neutron diffraction (PND) experiment was performed with the PUS diffractometer at the JEEP II reactor at the Institute for Energy Technology (IFE), Kjeller, Norway [20]. Neutrons with the wavelength $1.5539 \AA$ A were provided by a Ge(511) monochromator. The sample was contained in a cylindrical vanadium sample holder with $6 \mathrm{~mm}$ diameter. The diffracted neutrons were detected with two detector banks, each with 7 vertically stacked ${ }^{3} \mathrm{He}$ position-sensitive detector tubes covering a $20^{\circ}$ scattering angle. The $2 \theta$ range from 10 to $130^{\circ}$ was thus covered by moving each detector bank to three different positions. Rietveld refinements on the PND data were performed with GSAS [21] and expgui [22] employing a Pseudo-Voigt function according to Thompson et al. [23]. 2400 data points were refined using 38 parameters.

\subsection{Thermal Analysis}

Thermal analysis measurements (thermal gravimetry (TG) and differential scanning calorimetry (DSC)) were performed on a Mettler-Toledo TGA/DSC 1 instrument (Mettler-Toledo, Gießen, Germany) 
using a fully automated program for the evaluation of the data. The measurements were carried out in aluminum crucibles, which were filled in a glove box. For transportation, crucibles were closed to prevent any contact with air. For the measurements, the crucibles were opened under protective argon using typically $5-8 \mathrm{mg}$ of sample. Heating rates were $10^{\circ} \mathrm{C} \mathrm{min}^{-1}$.

\section{Results and Discussion}

The PXD patterns obtained after direct synthesis and after purification are shown in Figure 2. The successful synthesis of $\mathrm{RbAlH}_{4}$ from the elements is a proof of reversibility of de-and re-hydrogenation of this compound.

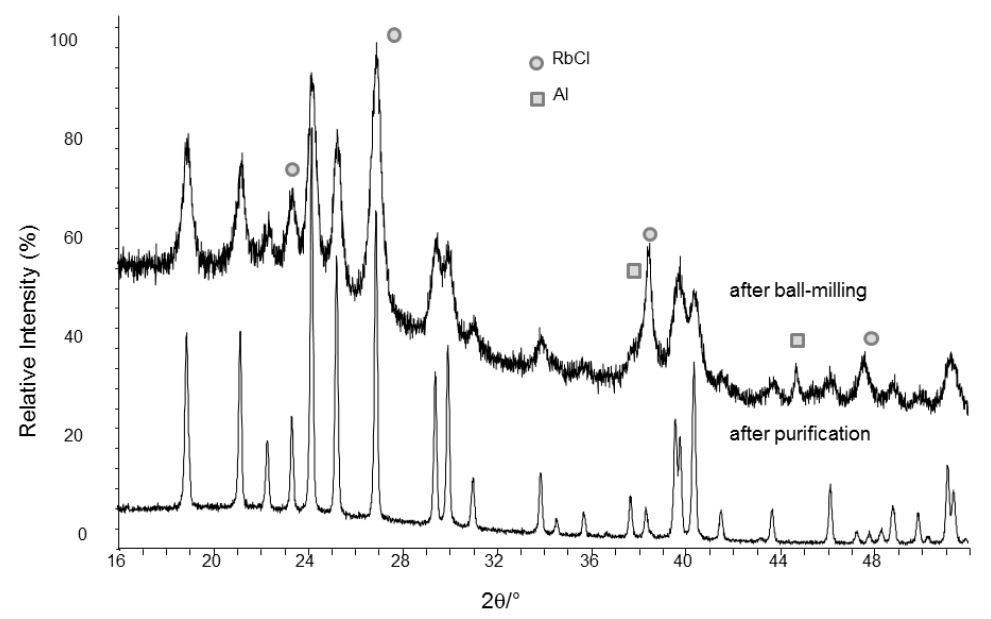

Figure 2. PXD patterns of $\mathrm{RbAlH}_{4}$ obtained by direct synthesis from $\mathrm{Rb}$ and $\mathrm{Al}$ metals according to Scheme 4 obtained directly after ball-milling and after purification. Data were collected on a laboratory instrument with $\mathrm{CuK} \alpha_{1}$ radiation $(1.54056 \AA$ ).

Rietveld refinements using the laboratory PXD data are based on the DFT structure predicted by Vajeeston et al. [16]. Refinement of the $\mathrm{Rb}$ and $\mathrm{Al}$ atomic positions results in a very good agreement between observed and calculated data (Figure S1, Supporting Information). Rietveld refinements (Figure 3) of PND data of $\mathrm{RbAlD}_{4}$ enable also the refinement of the deuterium positions. The refinements started with fixed isotropic thermal displacement parameters $\left(U_{\text {iso }}\right)$ with $0.01 \AA^{2}$ for $\mathrm{Rb}$ and $\mathrm{Al}$, and $0.05 \AA^{2}$ for $\mathrm{D}$. The Al-D bond distance was restrained to $1.64 \AA$. All restraints were removed at the final stage of the refinement and the thermal displacement factors were also refined. Crystallographic data of the predicted and the refined crystal structure are summarized in Table 1.

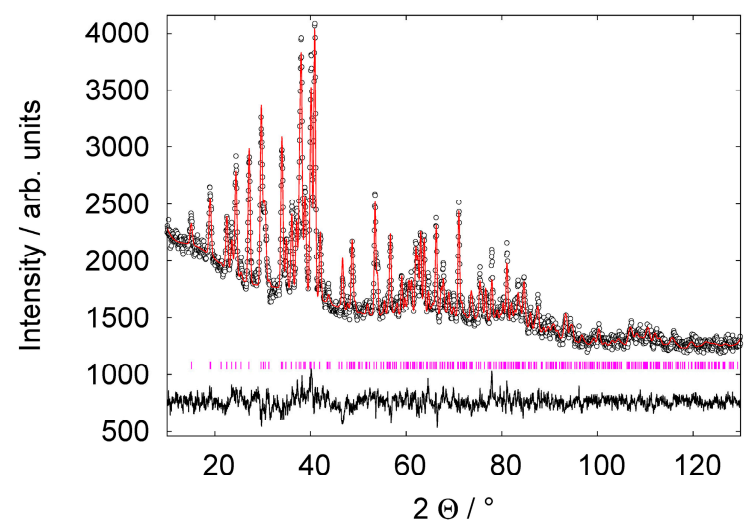

Figure 3. Final Rietveld refinement fit of PND data of $\mathrm{RbAlD}_{4}$. The wavelength used for data collection: $1.5539 \AA$. 
Table 1. Crystal structure data for $\mathrm{RbAlH}_{4} / \mathrm{RbAlD}_{4}$ predicted by DFT calculations [16] and obtained from crystal structure refinements of PND data (this work). Estimated standard deviations are given in parentheses.

\begin{tabular}{ccc}
\hline & Vajeeston et al. [16] & This Work PND \\
\hline $\mathrm{Rb}$ & $0.1823,1 / 4,0.1597$ & $0.1813(4), 1 / 4,0.1574(7)$ \\
$\mathrm{Al}$ & $0.5615,1 / 4,0.8138$ & $0.5639(5), 1 / 4,0.8121(7)$ \\
$\mathrm{H} / \mathrm{D} 1$ & $0.4017,1 / 4,0.8990$ & $0.4045(7), 1 / 4,0.9073(7)$ \\
$\mathrm{H} / \mathrm{D} 2$ & $0.6883,1 / 4,0.9610$ & $0.6884(7), 1 / 4,0.9615(8)$ \\
$\mathrm{H} / \mathrm{D} 3$ & $0.4198,0.9762,0.3121$ & $0.4204(4), 0.9691(6), 0.3080(6)$ \\
$\mathrm{a}(\AA)$ & 9.5956 & $9.2862(6)$ \\
$\mathrm{b}(\AA)$ & 5.7662 & $5.9392(3)$ \\
$\mathrm{c}(\AA)$ & 7.7795 & $7.5784(6)$ \\
$\mathrm{V}\left(\AA^{3}\right)$ & 430.44 & $417.97(5)$ \\
$\mathrm{U}_{\text {iso }} \mathrm{Rb}$ & & $0.028(1)$ \\
$\mathrm{U}_{\text {iso }} \mathrm{Al}$ & & $0.035(1)$ \\
$\mathrm{U}_{\text {iso }} \mathrm{D}$ & & $0.066(1)$ \\
$\mathrm{R}_{\mathrm{wp}}$ & & $3.1 \%$ \\
$\mathrm{R}_{\mathrm{B}}$ & & $16.7 \%$ \\
GOF & & 1.3 \\
\hline
\end{tabular}

The refined atomic positions match quite well with the predicted values. The refined lattice parameters match the values published by Bastide et al. [15]. However, the lattice parameters predicted by DFT calculations differ significantly from the experimental data. The crystal structure of $\mathrm{RbAlD}_{4}$ is isostructural with $\mathrm{KAlD}_{4}$ [24], which is built from isolated $\left[\mathrm{AlD}_{4}\right]^{-}$tetrahedra. The $\mathrm{Rb}$ cation is coordinated by $7\left[\mathrm{AlD}_{4}\right]^{-}$tetrahedra within a distance to the center $\mathrm{Al}$ cation in a range between 3.721 and $4.413 \AA$ (Figure 4a).

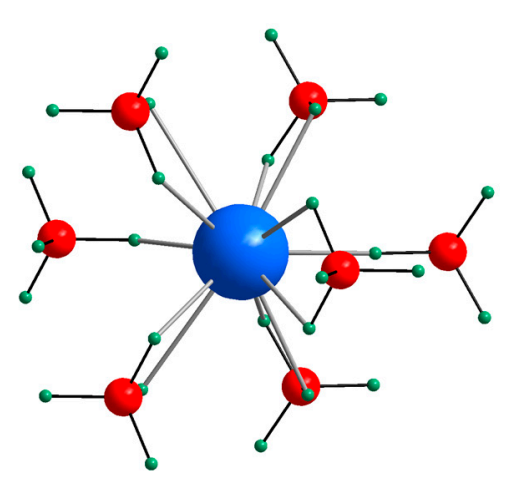

(a)

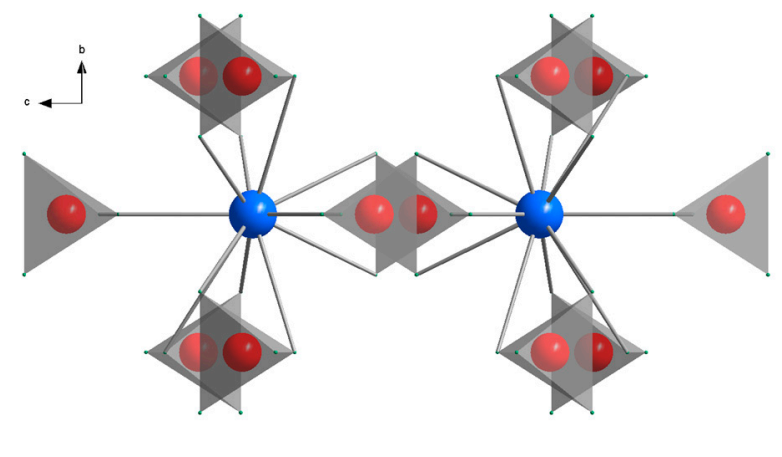

(b)

Figure 4. (a) First coordination sphere around the $\mathrm{Rb}$ cations by $7\left[\mathrm{AlD}_{4}\right]^{-}$units (primary building units). (b) Connectivity of the primary building units along the $c$-axis. (spheres: blue $\mathrm{Rb}$, red $\mathrm{Al}$, green D).

The decomposition properties were studied by thermal analysis (TG-DSC) and by PXD experiments. The samples were heated from room temperature only to $375^{\circ} \mathrm{C}$, because at temperatures above $400{ }^{\circ} \mathrm{C}$, the $\mathrm{Rb}$ metal formed during decomposition starts to evaporate (melting point of $\mathrm{Rb}$ : $39^{\circ} \mathrm{C}$ ). The TG-DSC measurement shows two endothermic events, the first one starting around $275^{\circ} \mathrm{C}$ and the second one at around $330^{\circ} \mathrm{C}$ (Figure 5). A weight loss of $1.6 \mathrm{wt} \%$ was observed for both decomposition steps. 


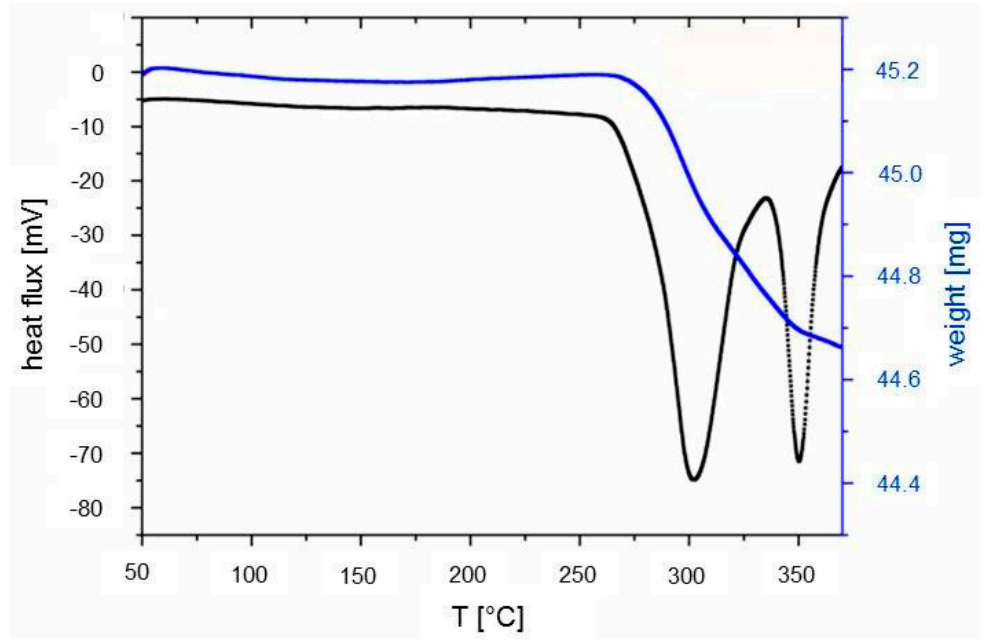

Figure 5. TG-DSC curves measured for $\mathrm{RbAlH} 4$ with a heating rate of $10{ }^{\circ} \mathrm{C} \mathrm{min}^{-1}$ showing two endothermic reactions.

This corresponds to only $45 \%$ of the theoretical weight loss if a complete decomposition to Rband Al-metal as final products is assumed. During the first thermal event, a multistep decomposition must take place, producing $\mathrm{RbH}$ and $\mathrm{Al}$-metal. The second decomposition step can be assigned to hydrogen release from $\mathrm{RbH}$ (decomposition temperature of $\mathrm{RbH} 364{ }^{\circ} \mathrm{C}$ [25]). The low amount of released hydrogen indicates either that the decomposition process was not completed under the experimental conditions or that other intermediates with higher hydrogen contents were produced during decomposition.

Dymova et al. studied the decomposition of $\mathrm{RbAlH}_{4}$ during heating under hydrogen pressure [26]. The decomposition of $\mathrm{RbAlH}_{4}$ to $\mathrm{Rb}_{3} \mathrm{AlH}_{6}$ was proposed in the temperature range between 317 and $334{ }^{\circ} \mathrm{C}$. A second decomposition between 390 and $417^{\circ} \mathrm{C}$ produces $\mathrm{RbH}$ from $\mathrm{Rb}_{3} \mathrm{AlH}_{6}$. No further information about the structural parameters of intermediate compounds such as $\mathrm{Rb}_{3} \mathrm{AlH}_{6}$ or precise experimental parameters was given.

The proposed decomposition mechanism is based on expected similarities to other decomposition reactions of complex aluminum hydrides as given in Scheme 1 . However, powder X-ray diffraction patterns collected at room temperature after heating to 300,325 and $350{ }^{\circ} \mathrm{C}$ (Figure 6) revealed an unexpectedly complicated decomposition behavior. According to the decomposition behavior of other complex aluminum hydrides such as $\mathrm{LiAlH}_{4}$ or $\mathrm{KAlH}_{4}$, a two-step decomposition with a hexahydride as intermediate was to be expected (Scheme 1). The sample studied after temperature treatment at $300{ }^{\circ} \mathrm{C}$ still contained some $\mathrm{RbAlH}_{4}$, but the presence of small amounts of $\mathrm{RbH}$ and $\mathrm{Al}$ indicated partial decomposition. However, the main reflection at about $30.3^{\circ} 2 \theta$ could not be explained by $\mathrm{RbH}$ or $\mathrm{Al}$. At least one intermediate decomposition product had formed, together with $\mathrm{RbH}$ and $\mathrm{Al}$. After heating to $325{ }^{\circ} \mathrm{C}, \mathrm{RbAlH}_{4}$ decomposed, and more $\mathrm{RbH}$ and $\mathrm{Al}$ were formed. The unidentified phase with the main reflection at $30.3^{\circ} 2 \theta$ was the main crystalline phase. At $350^{\circ} \mathrm{C}$, the unidentified phase had disappeared, and new reflections at 21.2, 25.5, and $30.0^{\circ} 2 \theta$ had appeared. This indicates the formation of an additional decomposition product. The crystal structure(s) of the intermediate phase(s) could not be determined, and are currently under investigation. We have first indications that kinetics is an important issue for decomposition, and that heating treatment is decisive whether intermediate decomposition phases can be monitored or not. 


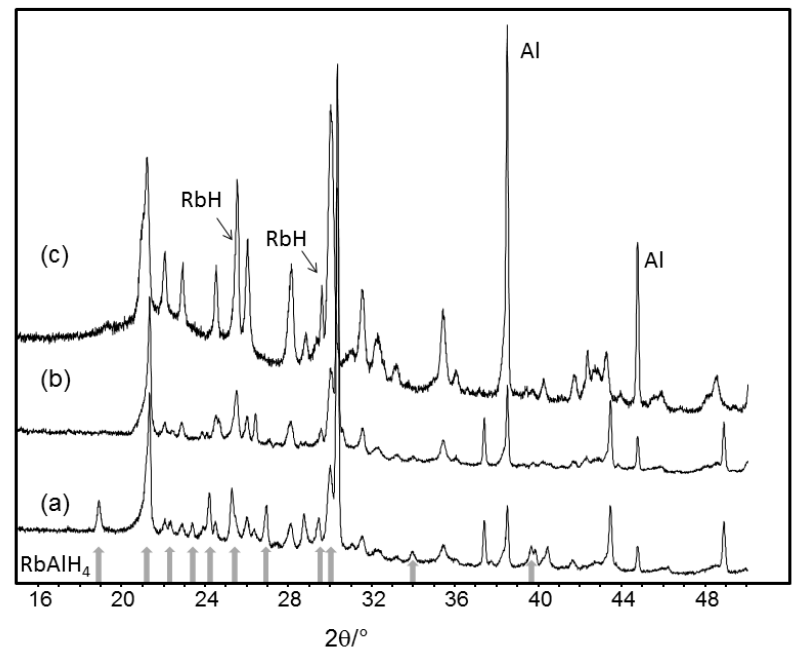

Figure 6. PXD patterns collected at room temperature after sample treatment at (a) $300{ }^{\circ} \mathrm{C},(\mathbf{b}) 325^{\circ} \mathrm{C}$, and $(\mathbf{c}) 350{ }^{\circ} \mathrm{C}$.

\section{Conclusions}

In summary, we report herein different synthesis routes for the preparation of $\mathrm{RbAlH}_{4}$. We were able to refine the crystal structure based on earlier published DFT calculations. Even though the crystal structure is isostructural with $\mathrm{KAlH}_{4}$, decomposition leads to the formation of new compounds. Decomposition studies show a complex hydrogen release that does not follow the expected sequence $\mathrm{RbAlH}_{4} \rightarrow \mathrm{Rb}_{3} \mathrm{AlH}_{6} \rightarrow \mathrm{RbH}$. The findings are the general basis for future in situ investigations.

Supplementary Materials: The following are available online at www.mdpi.com/2073-4352/8/2/103/s1. Figure S1: Rietveld refinement of $\mathrm{RbAlH}_{4}$ laboratory PXD data obtained from mechanochemical synthesis from $\mathrm{RbF}$ and $\mathrm{LiAlD}_{4}$ after purification.

Acknowledgments: CW gratefully acknowledges Jan Ternieden (MPI Mülheim for technical support).

Author Contributions: Claudia Weidenthaler and Michael Felderhoff conceived and designed the experiments; Daniel Krech performed the synthesis and TG-DSC experiments; Magnus H. Sørby and Bjørn C. Hauback performed the PND experiments and Thomas Bernert analyzed the data. Claudia Weidenthaler performed the decomposition experiments and wrote the paper.

Conflicts of Interest: The authors declare no conflict of interest.

\section{References}

1. Orimo, S.I.; Nakamori, Y.; Eliseo, J.R.; Züttel, A.; Jensen, C.M. Complex hydrides for hydrogen storage. Chem. Rev. 2007, 107, 4111-4132. [CrossRef] [PubMed]

2. Hauback, B. Structure of aluminium-based light weight hydrides. Z. Kristallogr. 2008, 223, 636-648. [CrossRef]

3. Weidenthaler, C.; Felderhoff, M. Complex Metal Hydrides: Handbook of Hydrogen Storage, New Materials for Future Energy Storage; Hirscher, M., Ed.; Wiley-VCH: Weinheim, Germany, 2010.

4. Fossdal, A.; Brinks, H.W.; Fichtner, M.; Hauback, B.C. Thermal decomposition of $\mathrm{Mg}\left(\mathrm{AlH}_{4}\right)_{2}$ studied by in situ synchrotron X-ray diffraction. J. Alloys Compd. 2005, 404-406, 752-756. [CrossRef]

5. Mamatha, M.; Bogdanović, B.; Felderhoff, M.; Pommerin, A.; Schmidt, W.; Schüth, F.; Weidenthaler, C. Mechanochemical preparation and investigation of properties of magnesium, calcium and lithium-magnesium alanates. J. Alloys Compd. 2006, 407, 78-86. [CrossRef]

6. Weidenthaler, C.; Frankcombe, T.J.; Felderhoff, M. First crystal structure studies of $\mathrm{CaAlH}_{5}$. Inorg. Chem. 2006, 45, 3849-3851. [CrossRef] [PubMed]

7. Sato, T.; Sørby, M.H.; Ikeda, K.; Sato, S.; Hauback, B.C.; Orimo, S. Syntheses, crystal structures, and thermal analyses of solvent-free $\mathrm{Ca}\left(\mathrm{AlD}_{4}\right)_{2}$ and CaAlD 5 . J. Alloys Compd. 2009, 487, 472-478. [CrossRef] 
8. Pommerin, A.; Wosylus, A.; Felderhoff, M.; Schüth, F.; Weidenthaler, C. Synthesis, crystal structures, and hydrogen-storage properties of $\mathrm{Eu}\left(\mathrm{AlH}_{4}\right)_{2}$ and $\mathrm{Sr}\left(\mathrm{AlH}_{4}\right)_{2}$ and of their decomposition intermediates, $\mathrm{EuAlH}_{5}$ and $\mathrm{SrAlH}_{5}$. Inorg. Chem. 2012, 51, 4143-4150. [CrossRef] [PubMed]

9. Zhang, Q.A.; Nakamura, Y.; Oikawa, K.I.; Kamiyama, T.; Akiba, E. New alkaline earth aluminum hydride with one-dimensional zigzag chains of $\left[\mathrm{AlH}_{6}\right]$ : Synthesis and crystal structure of $\mathrm{BaAlH}_{5}$. Inorg. Chem. 2002, 41, 6941-6943. [CrossRef] [PubMed]

10. Rönnebro, E.; Noréus, D.; Kadir, K.; Reiser, A.; Bodganović, B. Investigation of the perovskite related structures of $\mathrm{NaMgH}_{3}, \mathrm{NaMgF}_{3}$ and $\mathrm{Na}_{3} \mathrm{AlH}_{6}$. J. Alloys Compd. 2000, 299, 101-106. [CrossRef]

11. Krech, D.; Zibrowius, B.; Weidenthaler, C.; Felderhoff, M. On the preparation and structure of caesium aluminium tetrahydride. Eur. J. Inorg. Chem. 2014, 5683-5688. [CrossRef]

12. Bernert, T.; Krech, D.; Kockelmann, W.; Felderhoff, M.; Frankcombe, T.J.; Weidenthaler, C. Crystal structure relation between tetragonal and orthorhombic $\mathrm{CsAlD}_{4}$ : DFT and time-of-flight neutron powder diffraction studies. Eur. J. Inorg. Chem. 2015, 5545-5550. [CrossRef]

13. Adiks, T.G.; Gavrilenko, V.V.; Zakharkin, L.I.; Ignat'eva, L.A. Study of the infrared spectra of alkali metal aluminum hydrides. J. Appl. Spectrosc. 1967, 6, 546-551. [CrossRef]

14. Gavrilenko, V.V.; Chekulaeva, L.A.; Antonovich, V.A.; Zakharkin, L.I. Synthesis of aluminum hydride complex compounds containing the heptahydridodialuminate anion $\mathrm{Al}_{2} \mathrm{H}_{7}{ }^{-}$. Bull. Acad. Sci. USSR Div. Chem. Sci. 1977, 26, 2233-2237. [CrossRef]

15. Bastide, J.P.; El Hajri, J.; Claudy, P.; El Hajbi, A. A new route to alkali metal aluminum hydrides $\mathrm{MAlH}_{4}$ with $\mathrm{M}=\mathrm{Na}, \mathrm{K}, \mathrm{Rb}, \mathrm{Cs}$ and structural features for the whole family with $\mathrm{M}=\mathrm{Li}$ to Cs. Synth. React. Inorg. Met. Org. Chem. 1995, 25, 1037-1047. [CrossRef]

16. Vajeeston, P.; Ravindran, P.; Vidya, R.; Fjellvåg, H.; Kjekshus, A. Design of potential hydrogen-storage materials using first-principle density-functional calculations. Cryst. Growth Des. 2004, 3, 471-477. [CrossRef]

17. Pawelke, R.H.; Felderhoff, M.; Weidenthaler, C.; Schüth, F. Convenient synthesis of deuterated aluminium hydrides. Scr. Mater. 2008, 59, 515-517. [CrossRef]

18. Bellosta von Colbe, J.M.; Felderhoff, M.; Bogdanović, B.; Schüth, F.; Weidenthaler, C. One-step direct synthesis of a Ti-doped sodium alanate hydrogen storage material. Chem. Commun. 2005, 37, 4732-4734. [CrossRef] [PubMed]

19. Elansari, L.; Antoine, L.; Janot, R.; Gachon, J.C.; Kuntz, J.J.; Guérard, D. Preparation of alkali metal hydrides by mechanical alloying. J. Alloys Compd. 2001, 329, L5-L8. [CrossRef]

20. Hauback, B.C.; Fjellvåg, H.; Steinsvoll, O.; Johansson, K.; Buset, O.T.; Jørgensen, J. The high resolution powder neutron diffractometer PUS at the JEEP II reactor at Kjeller in Norway. J. Neutron Res. 2000, 8, 215. [CrossRef]

21. Larson, A.; Von Dreele, R. GSAS, Report LAUR 86-748; Los Alamos National Laboratory: Los Alamos, NM, USA, 2004.

22. Toby, B.H. EXPGUI, a graphical user interface for GSAS. J. Appl. Cryst. 2001, 34, 210-221. [CrossRef]

23. Thompson, P.; Cox, D.E.; Hastings, J.B. Rietveld refinement of Debye-Scherrer synchrotron X-ray data from $\mathrm{Al}_{2} \mathrm{O}_{3}$. J. Appl. Cryst. 1987, 20, 79-83. [CrossRef]

24. Hauback, B.C.; Brinks, H.W.; Heyn, R.H.; Blom, R.; Fjellvåg, H. The crystal structure of $\mathrm{KAlH}_{4}$. J. Alloys Compd. 2005, 394, 35-38. [CrossRef]

25. Hollemann-Wiberg. Lehrbuch der Anorganischen Chemie, 102 ed.; Walter der Gruyter: Berlin, Germany; New York, NY, USA, 2007; p. 1279.

26. Dymova, T.N.; Bakum, S.I.; Mirsaidov, U. Phase states of alkali aluminum hydrides. Dokl. Akad. Nauk SSSR 1974, 216, 87-90.

(C) 2018 by the authors. Licensee MDPI, Basel, Switzerland. This article is an open access article distributed under the terms and conditions of the Creative Commons Attribution (CC BY) license (http:/ / creativecommons.org/licenses/by/4.0/). 